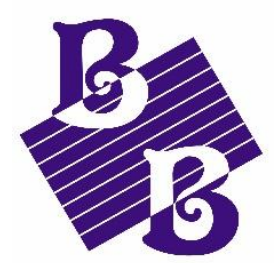

BioBacta

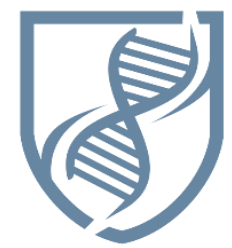

Journal of Bioscience and Applied Research www.jbaar.org

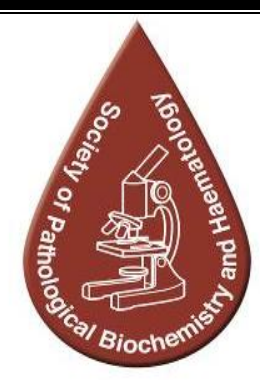

\title{
Suitability Assessment of Groundwater for Irrigation in Rabigh, Saudi Arabia: A Case Study of Combined Influence of Landfills and Saltwater Intrusion
}

\author{
Najla Mohsen Ali Al Ahmadi ${ }^{1,2}$, Furat Ahmed Mahmood Al-Faraj ${ }^{2,3}$, Nassir S. Alamri, ${ }^{1,4,5}$ \\ ${ }^{\mathbf{1}}$ General Authority of Meteorology and Environmental Protection \\ ${ }^{2}$ School of Civil Engineering and Built Environment, University of Bolton, United Kingdom \\ ${ }^{3}$ School of Computing, Science and Engineering, Civil Engineering Research Group, The University \\ of Salford, Newton Building, Greater Manchester M5 4WT, United Kingdom \\ ${ }^{4}$ Hydrology and Water Resources Management, King Abdulaziz University-Jeddah, Saudi Arabia \\ ${ }^{5}$ Presidency of Meteorology and Environment (PME), Saudi Arabia \\ (Corresponding Author: Dr. Furat Al-Faraj, Email: f.al-faraj@bolton.ac.uk; f.a.m.al-faraj1@ @alford.ac.uk)
}

DOI: $10.21608 /$ jbaar.2019.141083

\begin{abstract}
This research assessed the combined influence of permitted landfills and unlicensed dumps coupled with saltwater intrusion on the suitability of groundwater in Rabigh, Saudi Arabia for irrigation purposes. Fourteen water samples were analyzed for physiochemical parameters, major ions, and heavy metals. Quality assessment of groundwater for irrigation purposes was conducted on basis of sodium percentage (Na \%), sodium adsorption ratio (SAR), magnesium hazard $(\mathrm{MH})$, permeability index (PI), total hardness (TH), Kelley's ratio (KR), and soluble sodium percentage (SSP), Wilcox and the Food and Agriculture Organization of the United Nations (FAO) standard limits. Results showed that the domination of ions is in the order $\mathrm{Na}>\mathrm{Ca}>\mathrm{Mg}>\mathrm{K}$ and $\mathrm{Cl}>\mathrm{SO} 4>\mathrm{HCO} 3$ for cations and anions, respectively. Elevated concentration of $\mathrm{Na}$ and $\mathrm{Cl}$ coupled with very strong relationships between $\mathrm{Na}$ and $\mathrm{Cl}(\mathrm{r}=0.994), \mathrm{Na}$ and $\mathrm{EC}(\mathrm{r}=0.995)$, and between $\mathrm{Cl}$ and EC $(r=0.999)$ indicates a strong influence of Red Sea saltwater intrusion. According to Wilcox and the FAO classifications of salinity (Electrical conductivity (EC)) in irrigation water, it can be concluded that the groundwater in the investigated area of Rabigh is undesirable for irrigation purposes. Based on the Freeze and Cherry classification of total dissolved solids (TDS), the groundwater samples fall in the brackish to saline categories. However, saline water was recognized in the majority of the samples (64\%). Concerning the FAO classification, $86 \%$ of the samples can be classified in the severe restriction category. According to the categorization of irrigation water based on sodium percentage, two-thirds of the water samples can be classified in the doubtful to unsuitable categories. The very high electrical conductivity values obtained in the groundwater samples near the landfill sites are an indication of the combined effect of leachate and Red Sea saltwater intrusion. The severe restriction is associated with $65 \%$ of groundwater samples according to the FAO classification of SAR. Nearly two-thirds of the groundwater samples fall in the medium to high sodium hazard categories. According to Kelley's ratio and soluble sodium percent, the majority of the groundwater samples $(86 \%)$ show that the groundwater is undesirable for irrigation purposes. The analytical results of SSP conclude that the majority of groundwater samples $(86 \%)$ are undesirable for irrigated agriculture. Samples of some groundwater wells show that the concentration of some heavy metals such as Aluminum (Al), Cobalt $(\mathrm{Co})$, Copper $(\mathrm{Cu})$, Chromium $(\mathrm{Cr})$, Nickel $(\mathrm{Ni})$, Vanadium $(\mathrm{V})$, and Zinc $(\mathrm{Zn})$, are higher than the corresponding FAO permissible limits.
\end{abstract}

Key Words: Groundwater quality; Landfill; Seawater intrusion; Saudi Arabia; Irrigation; Contamination 


\section{Introduction}

The imbalance between available water resources and ever-increasing demands for the public and irrigation sectors has become a great concern to water managers as they attempt to sustainably manage limited water resources, especially in arid and semiarid regions (Al-Faraj and Scholz, 2014). Rapid population growth and socio-economic advancement coupled with climate change have exacerbated stress on water resources (Al-Faraj and Al-Dabbagh, 2015). In arid and semi-arid climate areas where precipitation is low and evapotranspiration rates are high, groundwater becomes a leading source of water to serve domestic, industrial, commercial, and irrigation sectors, especially in areas where perennial rivers are absent such as Saudi Arabia (Al-Hasawi and Hussein, 2012; Bhat et al., 2018).

An excessive abstraction of groundwater in many arid and semi-arid areas has several undesirable consequences such as lowering groundwater levels, degradation of the quality of groundwater, and saltwater intrusion in coastal areas. Alfarrah and Walraevens (2018) stated that heavy withdrawal of groundwater has increasingly become a crucial concern in recent decades, particularly in coastal arid and semi-arid regions. The intrusion of salty marine water may degrade water quality to levels exceeding permissible drinking and irrigation water standard limits, which can jeopardize future abstraction and availability of groundwater (Prasanth et al., 2012). A continuing rise in Sea levels due to global warming puts additional pressure and concern on future suitability and utilization of coastal aquifers, due to the increased threat of saltwater intrusion.

Understanding the effects of anthropogenic activities on groundwater quantity and quality is of paramount importance to the sustainable management of groundwater resources. Over-exploitation and reduced quality of groundwater influenced by sanitary landfilling, unlicensed dumping of solid waste, and disposal of wastewaters coupled with saltwater intrusion and rising of Sea levels, have become a growing concern and received special attention during the last two decades (Mukherjee et al., 2005; Al-Hasawi and Hussein, 2012; Shah and Mistry, 2013; Venkateswaran and Vediappan, 2013; Al-Faraj and Scholz, 2014; Singh et al., 2015; AlFaraj and Al-Dabbagh, 2015; Alfarrah and Walraevens, 2018; Bhat et al., 2018; General Authority of Meteorology and Environmental Protection (GAMEP), 2018).
Sanitary landfills are common environmental facilities and practices for waste management worldwide. However, in some parts of the world, particularly in areas where an absence of sanitary landfills is a critical issue, residents have been left with unlicensed indiscriminate use of open dumpsites and disposal of wastewaters (Oyiboka, 2014). Groundwater resources in areas adjacent to sanitary landfill sites and/or unauthorized open dumpsites and coastal areas are vulnerable to considerable contamination by leachates, unauthorized dumping, and invasion of Seawater (Bougioukou et al., 2005; Fami and Oluwole, 2013; Department for Environment, Food and Rural Affairs and Environment Agency, 2016; GAMEP, 2018).

Considerable attention over the last two decades has been also given to assessing the quality of groundwater near areas to landfills. Extensive research work has been carried out to examine the suitability of groundwater for agricultural irrigation near landfill sites (Mukherjee et al., 2005; Butt et al., 2008; Singh et al., 2015; Shah and Mistry, 2013; Venkateswaran and Vediappan, 2013; GAMEP, 2018).

Analysis and appropriate understanding of the quality of groundwater is crucial in determining its usability for public water supply and irrigation. Literature exhibited that extensive work has been conducted in this area (Mukherjee et al., 2005; Shah and Mistry, 2013; Venkateswaran and Vediappan, 2013; Singh et al., 2015; Narayanamurthi, 2018). In Saudi Arabia, the assessment of groundwater suitability for irrigation has been well received by many researchers (Al-Harbi, 2009; FAO, 2009; El-Hames, 2010; Khashogji and Maghraby, 2012; Al-Hasawi and Hussein, 2012). AlAhmadi (2012) stated that there are growing demands for groundwater usage due to increased anthropogenic activities associated with population growth.

This study aims to assess the quality of groundwater influenced by adjacent sanitary landfill and unlicensed dump sites, and saltwater intrusion of the Red Sea, for irrigation purposes. This, supports the establishment of a consistent long-term monitoring network and management program and plan, to successfully manage the groundwater sustainably.

\section{Materials and Methods}

2.1 Study area and the climate setting 
Rabigh is situated in Makkah, Saudi Arabia at a latitude of $22^{\circ} 47^{\prime} 54^{\prime \prime} \mathrm{N}$ and longitude of $39^{\circ} 02^{\prime} 05^{\prime \prime} \mathrm{E}$. Rabigh is located on the east coast of the Red Sea. It is characterized by intensive industrial activities (e.g. Arabian Cement Factory, Electric Power Plant, Water Supply Plant, Aramco Company Refinery, and Aramco Residential Area) and agricultural activities, and is considered to be one of the important industrial cities in Saudi Arabia. Its location will become more important and contribute to the economic development after the completion of King Abdullah Economic City, which is currently under construction about $40 \mathrm{~km}$ from Rabigh. The total area of Rabigh is 6,679 sq. $\mathrm{km}$ and the population based on the most recent census is 104,621 (GAMEP, 2018). Figure 1 shows the location of Rabigh and the study area.
A set of seven landfills is located in Al Jehfa in the south-east of Rabigh city about $16 \mathrm{~km}$ from Rabigh and $12 \mathrm{~km}$ from the coast of the Red Sea (Figure 1). Existing landfills in Rabigh receive waste from different sources such as households, fish farms, poultry farms, slaughter premises, industries, and small farms (GAMEP, 2018). Maximum monthly temperatures range from $28.2^{\circ} \mathrm{C}$ to $39.8^{\circ} \mathrm{C}$ and minimums between $17.7^{\circ} \mathrm{C}$ and $29.9^{\circ} \mathrm{C}$. Average monthly temperatures range between $22.9^{\circ} \mathrm{C}$ and $34.9^{\circ} \mathrm{C}$. Monthly rainfall records between 2013 and 2017 show that rainfall ranges between nil and 10.25 $\mathrm{mm}$ with total annual precipitation of $26.4 \mathrm{~mm}$ (GAMEP, 2018). Average monthly relative humidity ranges from $46.5 \%$ to $60 \%$ with an annual mean of $52.3 \%$.

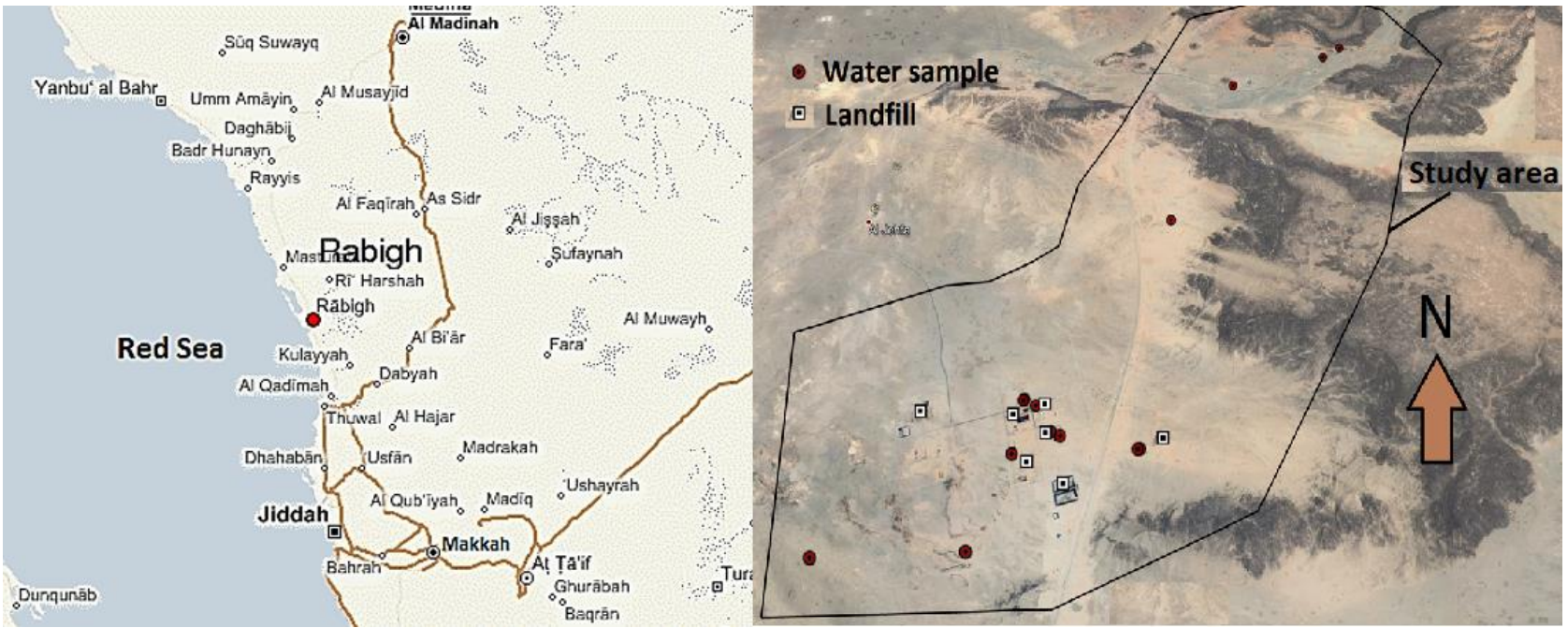

Figure 1 Location of the study area (Rabigh) in Saudi Arabia. 


\subsection{Data and Methods of Analysis}

This study investigates the suitability of groundwater in Rabigh for agricultural irrigation. Fourteen water samples including groundwater wells, farms, and disposal of wastewater, were made available by GAMEP. The parameters are Electrical conductivity (EC), Bicarbonate as CaCO3, Total Dissolved Solids (TDS), Sodium (Na), Calcium (Ca), Magnesium $(\mathrm{Mg})$, Potassium $(\mathrm{K})$, Chloride $(\mathrm{Cl})$, and Sulphate (SO4). Data of heavy metal elements: Aluminium (Al), Arsenic (As), Cadmium (Cd), Cobalt (Co), Copper $(\mathrm{Cu})$, Chromium (Cr), Nickle (Ni), Selenium $(\mathrm{Se})$, Vanadium $(\mathrm{V})$, and Zinc $(\mathrm{Zn})$ were also made available by GAMEP. The water samples were collected between September and October 2018.

Information about the geographical coordinates of the location of water samples and the seven landfill sites were also provided. The location of the seven landfills and the water samples is shown in Figure 1. Distances between the seven landfills and the location of the water samples were determined using Google Earth. An array $(7,14)$ is prepared to examine the impact of the distance between the landfill site (point source) and the location of the water sample (receptor) on the quality of groundwater.

Microsoft Excel was used to determine some descriptive statistics such as minimum, maximum, mean, and standard deviation. The suitability of groundwater for irrigation purposes in Rabigh was judged using seven indices that are commonly used worldwide. These indices are (1) Sodium Percentage (Wilcox, 1955 cited in Jeyaseelan et al., 2013), (2) Sodium Adsorption Ratio (Ayers and Westcot 1976 cited in Jeyaseelan et al., 2013), (3) Magnesium Hazard (Szabolcs and Darab, 1964 cited in Bhat et al., 2018), (4) Permeability Index (Doneen, 1964 cited in Bhat et al., 2016), (5) Total Hardness (Sawyer and McCarty, 1967 cited in Bhat et al., 2018), (6) Kelley's Ratio (Kelly, 1940 cited in Shah and Mistry, 2013 and Bhat et al., 2018), and (7) Soluble Sodium Percentage (Shah and Mistry, 2013). Table 1 shows the standard limits corresponding to the seven water quality indices for irrigation. The Wilcox and the FAO standard limits for irrigation water are given in Table 2.

Regression analysis was conducted to explore and model the relationship between different water quality parameters. Correlation coefficients between all investigated parameters were determined using the statistical tools available in Microsoft Excel.

\subsubsection{Sodium Percentage ( $\mathrm{Na} \%$ )}

High concentrations of sodium are undesirable in water. The sodium percentage is one of the important indices, which is widely used for judging the quality of water for irrigation purposes (Bhat et al., 2018). The $\mathrm{Na}$ is computed as the percentage of sodium and potassium against all cationic concentration (Ibraheem and Khan, 2017). Irrigation water is classified into different classes from excellent $(\mathrm{Na} \%)$ $<20$ to unsuitable $(\mathrm{Na} \%)>80$ (Table 1 ). The $\mathrm{Na} \%$ is computed using Equation 1. The calculated values are given in Table 3.

$$
\begin{aligned}
& \text { Sodium Percentage }(\mathrm{Na} \%)= \\
& \frac{\mathrm{Na}+K}{\mathrm{Ca}+\mathrm{Mg}+\mathrm{Na}+K} \mathrm{X} \text { 100----Equation } 1
\end{aligned}
$$

Where $\mathrm{Ca}, \mathrm{Mg}, \mathrm{Na}$, and $\mathrm{K}$ are measured in milliequivalents per liter

\subsubsection{Sodium Adsorption Ratio (SAR)}

Sodium adsorption ratio (SAR) is a universal indicator for assessing the degree of suitability of water for irrigated agriculture. The categorization of the suitability of groundwater for irrigation based on SAR is expressed in Table 1 (Joshi et al., 2009). SAR is calculated using Equation 2 and given in Table 3.

$$
\text { Sodium Adsportion Ratio }(S A R)=\frac{N a}{\sqrt{\frac{C a+M g}{2}}}
$$

Where $\mathrm{Ca}, \mathrm{Mg}$, and $\mathrm{Na}$ are measured in milliequivalents per liter

\subsubsection{Magnesium Hazard (MH \%)}

Magnesium hazard (MH) less than or equal to 50 is considered appropriate for irrigation whereas $\mathrm{MH}$ more than 50 indicates the unsuitability of water for irrigation (Szabolcs and Darab, 1964 cited in Bhat et al., 2018). With a high concentration of MH, soils become more alkaline coupled with a reduction in crop yield. Magnesium hazard is computed using the formula mentioned in Equation 3 (Bhat et al., 2018). The obtained values are given in Table 3 .

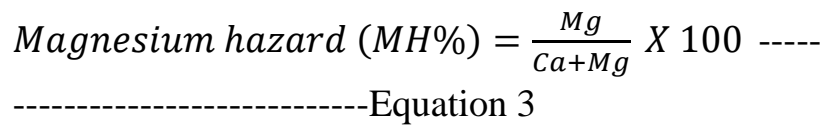

Where $\mathrm{Ca}$ and $\mathrm{Mg}$ are measured in milliequivalents per liter 


\subsubsection{Doneen's Permeability Index (PI\%)}

The prolonged use of irrigation water affects the permeability of soil as it is influenced by the presence of $\mathrm{Na}, \mathrm{Ca}, \mathrm{Mg}$, and bicarbonate $\mathrm{HCO} 3$ contents. According to Doneen's categorization (1964, cited in Bhat et al., 2018), waters can be classified as class I (Excellent with PI $>75 \%$ ), Class II (Good with $25 \leq \mathrm{PI} \leq 75$ ), and Class III (Unsuitable for $\mathrm{PI}<25$ ). Equation 4 is used to compute the permeability index. The computed values are given in Table 3.

Doneen's Permeability Index $(P I \%)=$

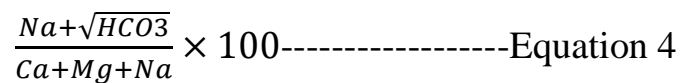

Where $\mathrm{Na}, \mathrm{Ca}, \mathrm{HCO} 3$ and $\mathrm{Mg}$ are measured in milligram per liter

\subsubsection{Total Hardness (TH)}

The total hardness (as CaCO3) of water samples can be estimated using Equation 5. Sawyer and McCarty (1967, cited in Bhat et al., 2018) proposed four classes to determine the suitability of water for irrigation (Table 1). Equation 5 is used to determine total hardness. Table 3 shows the computed values.

Total Hardness $\left(\right.$ as $\left.\mathrm{CaCO}_{3}\right)=2.5(\mathrm{Ca})+$ 4.1( $\mathrm{Mg})$-----------Equation 5

Where $\mathrm{Ca}$ and $\mathrm{Mg}$ are measured in milliequivalents per liter

\subsubsection{Kelley's Ratio (KR)}

Kelley's Ratio (KR) is a ratio of sodium ion concentration to the summation of $\mathrm{Ca}$ and $\mathrm{Mg}$ concentrations. Kelly's ratio of more than 1 indicates an excess level of $\mathrm{Na}$ in water. Water samples with Kelley's ratio less than 1 are considered suitable for irrigation whereas those with a ratio of more than 3 are considered unsuitable for irrigation. Kelly's ratio was computed using equation 6 (Kelly, 1963 cited in Shammi et al., 2016). The computed values are given in Table 3.

Kelley's Ratio $(K R)=\frac{N a}{C a+M g} \times 100$ -Equation 6

Where $\mathrm{Ca}, \mathrm{Mg}$, and $\mathrm{Na}$ are measured in milliequivalents per liter

\subsubsection{Soluble Sodium Percentage (SSP)}

Irrigation waters having SSP values of more than 50 are considered unsuitable (Shah and Mistry, 2013). SSP is computed using Equation 7 shown below. The computed values are shown in Table 3.

Soluable Sodium Percentage $($ SSP $)=$ $\frac{\mathrm{Na}}{\mathrm{Ca} \mathrm{Mg}+\mathrm{Na}} \times 100$---------------Equation 7

Where $\mathrm{Ca}, \mathrm{Mg}$, and $\mathrm{Na}$ are measured in milliequivalents per liter 
Table 1. Range of the seven indices and the corresponding water quality categories for irrigation purposes.

\begin{tabular}{|c|c|c|c|}
\hline Parameter & Range & Category & Source \\
\hline \multirow{5}{*}{ Sodium Percentage $(\mathrm{Na} \%)$} & $\mathrm{Na}<20$ & Excellent & \multirow{5}{*}{$\begin{array}{l}\text { (Wilcox, } 1955 \text { cited in } \\
\text { Jeyaseelan et al., 2013) }\end{array}$} \\
\hline & $20 \leq \mathrm{Na} \leq 40$ & Good & \\
\hline & $40<\mathrm{Na} \leq 60$ & Permissible & \\
\hline & $60<\mathrm{Na} \leq 80$ & Doubtful & \\
\hline & $\mathrm{Na}>80$ & Unsuitable & \\
\hline \multirow{5}{*}{ Sodium adsorption ratio (SAR) } & SAR $<2$ & No hazards & \multirow{5}{*}{$\begin{array}{l}\text { (Venkateswaran and } \\
\text { Vediappan, 2013) }\end{array}$} \\
\hline & $2 \leq \mathrm{SAR} \leq 10$ & Low hazards & \\
\hline & $10<\mathrm{SAR} \leq 18$ & Medium hazards & \\
\hline & $18<\mathrm{SAR} \leq 26$ & High hazards & \\
\hline & SAR $>26$ & Very high hazards & \\
\hline \multirow[b]{2}{*}{ Magnesium hazard (MH) (\%) } & $\mathrm{MH} \leq 50$ & Suitable & \multirow{2}{*}{$\begin{array}{l}\text { (Szabolcs and Darab, } \\
1964 \text { cited in Bhat et al., } \\
\text { 2018) }\end{array}$} \\
\hline & $\mathrm{MH}>50$ & Unsuitable & \\
\hline \multirow{3}{*}{ Doneen's Permeability index (PI) (\%) } & $\begin{array}{l}\mathrm{PI}<25 \\
\text { (class III) }\end{array}$ & Unsuitable & \multirow{3}{*}{$\begin{array}{l}\text { (Doneen, } 1964 \text { cited in } \\
\text { Bhat et al., 2018) }\end{array}$} \\
\hline & $\begin{array}{l}25 \leq \mathrm{PI} \leq 75 \\
\text { (class II) }\end{array}$ & Good & \\
\hline & PI $>75$ (class I) & Excellent & \\
\hline \multirow{4}{*}{ Total hardness $\left(\mathrm{TH}\right.$ as $\left.\mathrm{CaCO}_{3}\right)$} & $\mathrm{TH}<75$ & Soft & \multirow{4}{*}{$\begin{array}{l}\text { (Sawyer and } \\
\text { McCarty,1967 cited in } \\
\text { Bhat et al., 2018) }\end{array}$} \\
\hline & $75 \leq \mathrm{TH} \leq 150$ & Moderately hard & \\
\hline & $150<\mathrm{TH} \leq 300$ & Hard & \\
\hline & $\mathrm{TH}>300$ & Very hard & \\
\hline \multirow[b]{2}{*}{ Kelley's Ratio (KR) } & $\mathrm{KR} \leq 1$ & Suitable & \multirow{2}{*}{$\begin{array}{l}\text { (Kelley et al., } 1940 \text { cited } \\
\text { in Venkateswaran and } \\
\text { Vediappan, 2013) }\end{array}$} \\
\hline & $\mathrm{KR}>1$ & Unsuitable & \\
\hline \multirow{2}{*}{ Soluble Sodium Percentage (SSP) } & $\mathrm{SSP} \leq 50$ & Good & \multirow{2}{*}{ (Shah and Mistry, 2013) } \\
\hline & SSP>50 & Unsuitable & \\
\hline
\end{tabular}

Table 2. Wilcox and the FAO Standard limits for irrigation water.

\begin{tabular}{|c|c|}
\hline \multirow{4}{*}{$\begin{array}{l}\text { Electrical conductivity (EC) } \\
\text { (Wilcox, } 1955 \text { cited in Jeyaseelan et al., 2013) }\end{array}$} & Excellent $(100-250 \mu \mathrm{S} / \mathrm{cm})$ \\
\hline & Good $(250-750 \mu \mathrm{S} / \mathrm{cm})$ \\
\hline & Doubtful $(750-2250 \mu \mathrm{S} / \mathrm{cm})$ \\
\hline & Unsuitable $(>2250 \mu \mathrm{S} / \mathrm{cm})$ \\
\hline \multirow{9}{*}{ FAO (2009) } & No restriction $(\mathrm{EC}<700 \mu \mathrm{S} / \mathrm{cm})$ \\
\hline & Slight to moderate restriction $(700 \leq \mathrm{EC} \leq 3000 \mu \mathrm{S} / \mathrm{cm})$ \\
\hline & Severe restriction $(\mathrm{EC}>3000 \mu \mathrm{S} / \mathrm{cm})$ \\
\hline & No restriction (TDS $<450 \mathrm{mg} / \mathrm{l})$ \\
\hline & Slight to moderate restriction $450 \leq \mathrm{TDS} \leq 2000 \mathrm{mg} / 1$ \\
\hline & Severe restriction $(\mathrm{TDS}>2000 \mathrm{mg} / \mathrm{l})$ \\
\hline & No restriction $(\mathrm{SAR}<3 \mathrm{meq} / \mathrm{l})$ surface irrigation \\
\hline & $\begin{array}{l}\text { Slight to moderate restriction } 3 \leq \mathrm{SAR} \leq 9 \mathrm{meq} / \mathrm{l} \text { surface } \\
\text { irrigation }\end{array}$ \\
\hline & Severe restriction $(S A R>9 \mathrm{meg} / \mathrm{l})$ surface irrigation \\
\hline Element & FAO Standard limits for irrigation water (mg/l) \\
\hline Al & 5.0 \\
\hline As & 0.1 \\
\hline $\mathrm{Cd}$ & 0.1 \\
\hline $\mathrm{Cr}$ & 0.1 \\
\hline Co & 0.05 \\
\hline $\mathrm{Cu}$ & 0.2 \\
\hline $\mathrm{Fe}$ & 5.0 \\
\hline $\mathrm{Pb}$ & 5.0 \\
\hline $\mathrm{Mn}$ & 0.2 \\
\hline $\mathrm{Ni}$ & 0.2 \\
\hline $\mathrm{Se}$ & 0.02 \\
\hline $\mathrm{V}$ & 0.1 \\
\hline $\mathrm{Zn}$ & 2.0 \\
\hline
\end{tabular}




\section{Results and Discussion}

\subsection{Irrigation Water Quality}

\subsubsection{Sodium Percentage (Na \%)}

The computed sodium percentage values using vary between $41.8 \%$ and $80.8 \%$. Results (Table 3 ) show that approximately $36 \%$ of the water samples fall within the permissible levels for agricultural irrigation $(40<\mathrm{Na} \leq 60)$, nearly $(7 \%)$ are considered inappropriate $(\mathrm{Na}>80)$ while the doubtful levels $(60<\mathrm{Na} \leq 80)$ are linked to the remaining $(57 \%)$.

\subsubsection{Sodium Adsorption Ratio (SAR)}

The sodium adsorption ratio (SAR) is an irrigation water quality index widely used to assess the sodium hazards to soil and crops. It is a measure of the amount of sodium $(\mathrm{Na})$ relative to calcium $(\mathrm{Ca})$ and magnesium $(\mathrm{Mg})$ in a water sample. The sodium in the irrigation water can displace the calcium and magnesium in the soil; if high SAR irrigation water is supplied over a long period, the soil infiltration rate and soil permeability will be reduced, leading to crop damage or reduce crop production. The SAR values of the water samples vary between 1.4 and 25.9. Results (Table 3) suggest that $50 \%$ of water samples are within the medium sodium hazard limits, nearly $22 \%$ linked to the low sodium hazard range. Groundwater samples associated with no sodium hazard and high sodium hazard each came with approximately $14 \%$ of the water samples. Regarding the FAO standard limits, results exhibit that no restriction to use groundwater for irrigation is associated with $21 \%$; $14 \%$ of the samples fall within the limits of slight to moderate restriction, while the remaining $65 \%$ are linked to severe restriction.

\subsubsection{Magnesium Hazard (MH)}

Venkateswaran and Vediappan (2013) stated that excess levels of magnesium in groundwater affect the quality of soils, which reduces crop yield. The computed magnesium hazard $(\mathrm{MH})$ values range between $17.7 \%$ and $60.2 \%$. Results (Table 3) recommend that almost (93\%) of the water samples are suitable for irrigation, while the remaining (7\%) are considered unsuitable.

\subsubsection{Doneen's Permeability index (PI)}

Soil permeability is affected by a prolonged supply of irrigation water (Patel and Dhiman, 2017). The computed PI values of the water samples vary between $49.2 \%$ and $84.6 \%$. Results (Table 3 ) reveal that approximately $14 \%$ of the water samples fall in class I (PI>75: Excellent), while the remaining (86\%) are considered good for agricultural irrigation (class II: $25 \leq$ PI $\leq 75$ ).

\subsubsection{Total Hardness (as CaCO3)}

Results (Table 3) conclude that the total hardness of the water samples varies between approximately 27 and 1535 milliequivalents per liter. This suggests that soft hardness is linked to nearly $22 \%$ of the water samples, moderately hardness is associated with approximately $14 \%$, about $7 \%$ falls within the hard class, while the remaining $57 \%$ fall within the very hard class.

\subsubsection{Kelley's Ratio (KR)}

In equation 6, the sodium level in groundwater is measured against the calcium and magnesium. Kelley's ratio (KR) of more than 1 suggests an excess level of sodium in water samples. Therefore, water samples with a KR less than 1 are considered suitable for irrigation, while those with a KR of more than 1 are unfit for irrigation. The computed KR values vary between 0.70 and 4.1. The minimum value is associated with well 3CW1 while the maximum value is linked to the well 6AW1-Salih farm. Results (Table 3) reveal that approximately (14\%) of the water samples have good quality water for irrigation, while the unsuitable water quality for irrigation is associated with the remaining (86\%).

\subsubsection{Soluble Sodium Percent (SSP)}

The computed values of SSP vary between 40.2 and 80.6 (Table 3). $14 \%$ of SSP values were found less than 50 indicating good quality water for irrigation, while the remaining $86 \%$ are associated with unsuitable water quality for irrigation purposes. 
Table 3. Calculated values of the seven water quality indices

\begin{tabular}{|l|l|l|l|l|l|l|l|}
\hline Sample & Na\% & SAR & MH & PI & TH & KR & SSP \\
\hline 4BW1-Waste water disposal site & 60.59 & 13.76 & 42.62 & 67.72 & 1050.79 & 1.51 & 60.22 \\
\hline AW1-Almustadama landfill & 77.78 & 25.86 & 35.45 & 82.24 & 686.55 & 3.46 & 77.57 \\
\hline AW2-Almustadama landfill & 65.84 & 17.17 & 43.54 & 72.64 & 1033.29 & 1.91 & 65.64 \\
\hline BW1-GEMS landfill & 61.87 & 16.84 & 35.19 & 68.27 & 1339.78 & 1.61 & 61.69 \\
\hline BW2-GEMS landfill & 64.88 & 17.75 & 35.62 & 71.07 & 1149.17 & 1.84 & 64.73 \\
\hline 3BW1-Phil landfill & 62.50 & 18.48 & 35.75 & 68.89 & 1534.76 & 1.65 & 62.31 \\
\hline 3BW2-SEPCO landfill & 62.99 & 16.52 & 35.98 & 69.35 & 1181.91 & 1.69 & 62.77 \\
\hline 3CW1-Phil landfill & 43.14 & 1.57 & 17.68 & 49.17 & 50.54 & 0.74 & 42.44 \\
\hline 3CW2-Afaq landfill & 56.26 & 13.11 & 36.39 & 63.11 & 1303.53 & 1.27 & 56.04 \\
\hline 4BW2-Nabe'a Farm & 65.23 & 2.61 & 47.65 & 75.18 & 26.49 & 1.83 & 64.68 \\
\hline 5AW1-Rashid Farm & 58.81 & 5.56 & 28.65 & 65.26 & 181.00 & 1.42 & 58.70 \\
\hline 6AW1-Salih Farm & 80.78 & 11.80 & 28.93 & 84.59 & 96.09 & 4.14 & 80.55 \\
\hline 6BW1-Jama'an Farm & 57.77 & 4.46 & 25.81 & 63.59 & 128.19 & 1.34 & 57.33 \\
\hline 6CW1-Kuleya Village & 41.83 & 1.39 & 60.25 & 53.76 & 54.89 & 0.70 & 41.16 \\
\hline Min & 41.83 & 1.39 & 17.68 & 49.17 & 26.49 & 0.70 & 41.16 \\
\hline Max & 80.78 & 25.86 & 60.25 & 84.59 & 1534.76 & 4.14 & 80.55 \\
\hline Mean & 61.45 & 11.92 & 36.39 & 68.20 & 701.21 & 1.79 & 61.13 \\
\hline Dev.S* & 10.59 & 7.60 & 10.25 & 9.49 & 581.20 & 0.94 & 10.72 \\
\hline
\end{tabular}

* Standard deviation

\subsubsection{Wilcox-FAO Standard Limits}

The EC is a good indicator of salinity hazards to crops when groundwater is used for irrigation. According to Wilcox (1955), groundwater was classified into four categories: Excellent $(100-250 \mu \mathrm{S} / \mathrm{cm})$, Good (250-750 $\mu \mathrm{S} / \mathrm{cm})$, Doubtful $(750-2250 \mu \mathrm{S} / \mathrm{cm})$, and Unsuitable $(>2250 \mu \mathrm{S} / \mathrm{cm})$. Concerning the FAO classification, there is no degree of restriction to the irrigation water when $\mathrm{EC}<700 \mu \mathrm{S} / \mathrm{cm}$, slight to moderate restriction when $(700 \mu \mathrm{S} / \mathrm{cm}$ $\leq \mathrm{EC} \leq 3000 \mu \mathrm{S} / \mathrm{cm}$ ), and severe restriction when $\mathrm{EC}>3000 \mu \mathrm{S} / \mathrm{cm}$. The EC values (Table 4 ) of water samples range between $2310 \mu \mathrm{S} / \mathrm{cm}$ and $116000 \mu \mathrm{S} / \mathrm{cm}$ with a mean value of $56678.6 \mu \mathrm{S} / \mathrm{cm}$ and a standard deviation of $44644.2 \mu \mathrm{S} / \mathrm{cm}$. This suggests the unsuitability of water for irrigation. The maximum value was associated with well 3BW1-Phil landfill followed by $99900 \mu \mathrm{S} / \mathrm{cm}$ and $96500 \mu \mathrm{S} / \mathrm{cm}$, which are linked to well BW1-GEMS landfill and well AW1-Almustadama landfill, respectively. The minimum value was associated with the well 4BW2-Nabe'a farm. The large value of the standard deviation $(44644.2 \mu \mathrm{S} / \mathrm{cm})$ indicates that EC values vary widely between the examined water samples.
Results (Table 4) revealed that the dominance of cations is in the order $\mathrm{Na}>\mathrm{Ca}>\mathrm{Mg}>\mathrm{K}$. The corresponding concentrations range between 255 and $19000 \mathrm{mg} / \mathrm{l}, 85$ and $6420 \mathrm{mg} / \mathrm{l}, 39$ and $2170 \mathrm{mg} / \mathrm{l}$; and 12 and $369 \mathrm{mg} / \mathrm{l}$, respectively. The corresponding means and standard deviations are 9225.4 and 7461.5 $\mathrm{mg} / \mathrm{l}, 2859.8$ and $2366.5 \mathrm{mg} / \mathrm{l}, 1018.6$ and $854.6 \mathrm{mg} / \mathrm{l}$, and 152.6and $121.3 \mathrm{mg} / \mathrm{l}$, respectively. The concentrations of anions declined in the order $\mathrm{Cl}>\mathrm{SO} 4$. The corresponding minimum, maximum, mean, and standard deviation values are 483, 44900, 21457.7, and 17641.8 mg/l, and 258, 3200, 1559.6, and $920.5 \mathrm{mg} / \mathrm{l}$, respectively. The most abundant cation $(\mathrm{Na})$ and anion $(\mathrm{Cl})$ are linked to a well 3BW1-Phil landfill.

The normal range of $\mathrm{pH}$ for agricultural irrigation is from 6.5 to 8.4 (FAO, n.d.). The $\mathrm{pH}$ values of groundwater samples vary between 4.58 and 8.08 (Table 4). This suggests that the $\mathrm{pH}$ values in all surveyed wells except the well (3CW2-Afaq landfill: $\mathrm{pH}=4.58$ ) are well within the standard limits prescribed by the FAO. An abnormal value observed in well-3CW2-Afaq landfill is a warning that the water quality needs further investigation. 
The concentrations of bicarbonate ( $\mathrm{HCO} 3)$ in all examined groundwater wells (Table 4) vary between 38 and $206 \mathrm{mg} / \mathrm{l}$, which are within the permitted limits of FAO (Gameh et al., 2014) for irrigation (610 $\mathrm{mg} / \mathrm{l})$.

Freeze and Cherry (1979) classified water into four categories depending on the TDS value: Freshwater (TDS: 0-1000 mg/l); Brackish water (TDS: 100010,000 mg/l); Saline water (TDS: 10,000-100,000 $\mathrm{mg} / \mathrm{l}$ ); and Brine water (TDS $>100,000 \mathrm{mg} / \mathrm{l}$ ). As far as TDS values are concerned (Table 4), the maximum value of $80300 \mathrm{mg} / \mathrm{l}$ is associated with well 3BW1-Phil landfill followed by $70500 \mathrm{mg} / \mathrm{l}$ linked to well BW1-GEMS landfill. The minimum, maximum, mean, and standard deviation are 1490, 80300, 38458.6, and $30855.5 \mathrm{mg} / \mathrm{l}$, respectively. Results conclude that $36 \%$ of the groundwater samples are classified as brackish water, while the remaining $64 \%$ as saline water. Concerning the FAO standard limits, results demonstrate that slight to moderate restriction is associated with $14 \%$ of the samples, while the severe restriction is linked to the remaining $86 \%$.

The concentrations of the heavy metals (Table 5) were compared with the FAO maximum allowable limits (Table 2). $\mathrm{Al}, \mathrm{Co}, \mathrm{Cu}, \mathrm{Cr}, \mathrm{Ni}$, and $\mathrm{V}$ were detected in the 4BW1-Wastewater disposal site and
3BW2-SEPCO landfill at levels higher than the permissible concentration limits. The corresponding values are $681 \mathrm{mg} / \mathrm{l}$ and $235 \mathrm{mg} / \mathrm{l}, 0.64 \mathrm{mg} / \mathrm{l}$ and $0.16 \mathrm{mg} / \mathrm{l}, 1.16 \mathrm{mg} / \mathrm{l}$ and $0.261 \mathrm{mg} / 1,2.96 \mathrm{mg} / \mathrm{l}$ and $0.792 \mathrm{mg} / 1,3.73 \mathrm{mg} / \mathrm{l}$ and $0.734 \mathrm{mg} / \mathrm{l}$ and $3.0 \mathrm{mg} / \mathrm{l}$ and $0.65 \mathrm{mg} / \mathrm{l}$, respectively. Selenium was found in a well $5 \mathrm{AW} 1-$ Rashi farm at a concentration of $(0.03 \mathrm{mg} / \mathrm{l})$, which is slightly above the FAO standard limit of $0.02 \mathrm{mg} / \mathrm{l}$. Zinc was distinguished in three wells, 4BW1-Wastewater disposal site $(8.62 \mathrm{mg} / \mathrm{l})$, BW2-GEMS landfill, and 3BW1-Phil landfill of $3.44 \mathrm{mg} / \mathrm{l}$ at a level exceeding the permissible limit of $2.0 \mathrm{mg} / \mathrm{l}$. As and $\mathrm{Cd}$ values (Table 5) are less than the FAO standard limits.

Aluminium was seen in the water samples of a 3BW2-GEMS landfill and 4BW1-Wastewater disposal site at levels that exceeded the permissible limit. The corresponding concentrations are $235 \mathrm{mg} / \mathrm{l}$ and $681 \mathrm{mg} / \mathrm{l}$, respectively. As and $\mathrm{Cd}$ values (Table 5 ) are less than the FAO permissible limits. However, Iron and Manganese were found in 4BW1-Wastewater disposal sites at levels higher than permissible limits. The corresponding concentrations are $1170 \mathrm{mg} / \mathrm{l}$ and $16.2 \mathrm{mg} / \mathrm{l}$, respectively. The FAO maximum recommended values of Iron and Manganese in irrigation are 5.0 and $0.5 \mathrm{mg} / \mathrm{l}$, respectively (FAO, n.d.).

Table 4. Concentrations of various parameters of the water samples.

\begin{tabular}{|l|l|l|l|l|l|l|l|l|l|l|}
\hline Sample & $\begin{array}{l}\mathbf{E C} \\
(\boldsymbol{\mu S} / \mathbf{c m})\end{array}$ & $\begin{array}{l}\mathbf{N a} \\
(\mathbf{m g} / \mathbf{l})\end{array}$ & $\begin{array}{l}\mathbf{C a} \\
(\mathbf{m g} / \mathbf{l})\end{array}$ & $\begin{array}{l}\mathbf{M g} \\
(\mathbf{m g} / \mathbf{l})\end{array}$ & $\begin{array}{l}\mathbf{K} \\
(\mathbf{m g} / \mathbf{l})\end{array}$ & $\begin{array}{l}\mathbf{C l} \\
(\mathbf{m g} / \mathbf{l})\end{array}$ & $\begin{array}{l}\mathbf{S O 4} \\
(\mathbf{m g} / \mathbf{l})\end{array}$ & $\mathbf{p H}$ & $\begin{array}{l}\text { HCO3 } \\
(\mathbf{m g} / \mathbf{l})\end{array}$ & $\begin{array}{l}\text { TDS } \\
(\mathbf{m g} / \mathbf{l})\end{array}$ \\
\hline 4BW1-Waste water disposal site & 73100 & 11500 & 3790 & 1710 & 299 & 26900 & 1940 & 6.88 & 134 & 48700 \\
\hline AW1-Almustadama landfill & 96500 & 17800 & 2890 & 964 & 369 & 37200 & 2770 & 6.95 & 62 & 67100 \\
\hline AW2-Almustadama landfill & 84200 & 14200 & 3650 & 1710 & 214 & 32100 & 2310 & 7.02 & 71 & 47400 \\
\hline BW1-GEMS landfill & 99900 & 16200 & 5670 & 1870 & 216 & 38700 & 1760 & 6.98 & 68 & 70500 \\
\hline BW2-GEMS landfill & 95500 & 15800 & 4820 & 1620 & 178 & 37000 & 2080 & 7.13 & 48 & 67400 \\
\hline 3BW1-Phil landfill & 116000 & 19000 & 6420 & 2170 & 253 & 44900 & 1940 & 6.81 & 38 & 80300 \\
\hline 3BW2-SEPCO landfill & 92100 & 14900 & 4920 & 1680 & 242 & 35700 & 1620 & 6.48 & 99 & 64100 \\
\hline 3CW1-Phil landfill & 3330 & 308 & 299 & 39 & 15 & 483 & 929 & 7.97 & 93 & 2170 \\
\hline 3CW2-Afaq landfill & 86500 & 12400 & 5380 & 1870 & 192 & 33800 & 1530 & 4.58 & 0.8 & 60200 \\
\hline 4BW2-Nabe'a Farm & 2310 & 342 & 85 & 47 & 14 & 542 & 282 & 7.58 & 206 & 1490 \\
\hline 5AW1-Rashid Farm & 15200 & 2000 & 873 & 213 & 15 & 3280 & 320 & 7.12 & 192 & 9960 \\
\hline 6AW1-Salih Farm & 16300 & 3090 & 461 & 114 & 75 & 5320 & 886 & 7.03 & 108 & 10800 \\
\hline 6BW1-Jama'an Farm & 9910 & 1360 & 653 & 138 & 42 & 3820 & 258 & 7.15 & 62 & 6560 \\
\hline 6CW1-Kuleya Village & 2650 & 255 & 126 & 116 & 12 & 663 & 329 & 8.08 & 148 & 1740 \\
\hline Min & 2310 & 255 & 85 & 39 & 12 & 483 & 258 & 4.58 & 38 & 1490 \\
\hline Max & 116000 & 19000 & 6420 & 2170 & 369 & 44900 & 2770 & 8.08 & 206 & 80300 \\
\hline Mean & 56678.6 & 9225.4 & 2859.8 & 1018.6 & 152.6 & 21457.7 & 1353.8 & 7.00 & 102.2 & 38458.6 \\
\hline Dev.S & 44644.2 & 7461.4 & 2366.5 & 854.65 & 121.35 & 17641.8 & 844.4 & 0.8 & 53.6 & 30855.5 \\
\hline
\end{tabular}


Table 5. Concentrations of the heavy metals of the water samples.

Values marked in Bold are higher than the standard limits.

\begin{tabular}{|l|l|l|l|l|l|l|l|l|l|l|}
\hline \multirow{2}{*}{ Sample } & \multicolumn{9}{|c|}{ Mg/ } \\
\cline { 2 - 10 } & $\mathbf{A l}$ & $\mathbf{A s}$ & $\mathbf{C d}$ & $\mathbf{C o}$ & $\mathbf{C u}$ & $\mathbf{C r}$ & $\mathbf{N i}$ & $\mathbf{S e}$ & $\mathbf{V}$ & $\mathbf{Z n}$ \\
\hline 4BW1-Wastewater disposal site & $\mathbf{6 8 1}$ & 0.059 & 0.0014 & $\mathbf{0 . 6 4}$ & $\mathbf{1 . 1 6}$ & $\mathbf{2 . 9 6}$ & $\mathbf{3 . 7 3}$ & $<0.01$ & $\mathbf{3 . 0 0}$ & $\mathbf{3 . 1 7}$ \\
\hline AW1-Almustadama landfill & 1.06 & $<0.001$ & $<0.0001$ & $<0.001$ & $<0.001$ & $<0.001$ & $<0.010$ & $<0.01$ & $<0.01$ & 0.171 \\
\hline AW2-Almustadama landfill & 1.74 & $<0.001$ & $<0.0001$ & $<0.001$ & $<0.001$ & $<0.012$ & 0.0110 & $<0.01$ & $<0.01$ & 0.100 \\
\hline BW1-GEMS landfill & 0.55 & $<0.001$ & $<0.0001$ & $<0.001$ & $<0.001$ & $<0.001$ & $<0.001$ & $<0.01$ & $<0.01$ & $\mathbf{8 . 6 2 0}$ \\
\hline BW2-GEMS landfill & $<0.02$ & $<0.002$ & $<0.0002$ & $<0.002$ & 0.0020 & $<0.002$ & $<0.002$ & $<0.02$ & $<0.02$ & $\mathbf{3 . 4 4 0}$ \\
\hline 3BW1-Phil landfill & 4.75 & $<0.002$ & $<0.0002$ & $<0.002$ & 0.0210 & 0.0260 & $<0.002$ & $<0.02$ & $<0.02$ & $\mathbf{3 . 4 4 0}$ \\
\hline 3BW2-SEPCO landfill & $\mathbf{2 3 5}$ & 0.0320 & $<0.0002$ & $\mathbf{0 . 1 6 0}$ & $\mathbf{0 . 2 6 1 0}$ & $\mathbf{0 . 7 9 2 0}$ & 0.7340 & $<0.02$ & $\mathbf{0 . 6 5}$ & 0.555 \\
\hline 3CW1-Phil landfill & 0.45 & $<0.001$ & $<0.0001$ & $<0.001$ & $<0.001$ & $<0.001$ & 0.0020 & $<0.01$ & 0.01 & 0.052 \\
\hline 3CW2-Afaq landfill & 0.45 & $<0.001$ & $<0.0001$ & $<0.001$ & $<0.001$ & $<0.001$ & $<0.001$ & $<0.01$ & $<0.01$ & $<0.005$ \\
\hline 4BW2-Nabe'́a Farm & $<0.01$ & $<0.001$ & $<0.0001$ & $<0.001$ & $<0.001$ & $<0.001$ & $<0.001$ & $<0.01$ & 0.01 & 0.008 \\
\hline 5AW1-Rashid Farm & $<0.01$ & $<0.001$ & $<0.0001$ & $<0.001$ & $<0.001$ & $<0.001$ & $<0.001$ & $\mathbf{0 . 0 3}$ & 0.02 & $<0.005$ \\
\hline 6AW1-Salih Farm & $<0.01$ & $<0.001$ & $<0.0001$ & $<0.001$ & $<0.001$ & $<0.001$ & $<0.001$ & $<0.01$ & $<0.01$ & 0.044 \\
\hline 6BW1-Jama'́an Farm & $<0.01$ & $<0.001$ & $<0.0001$ & $<0.001$ & 0.0030 & $<0.001$ & $<0.001$ & $<0.01$ & $<0.01$ & $<0.005$ \\
\hline 6CW1-Kuleya Village & $<0.01$ & $<0.001$ & $<0.0001$ & $<0.001$ & $<0.001$ & 0.003 & 0.002 & $<0.01$ & 0.01 & 0.047 \\
\hline
\end{tabular}

3.2 Distance between the location of water samples and existing landfills

Table 6 shows the distances between the location of the water samples and the existing landfills in Rabigh. Results show that the distances vary between a few meters to 14.4 kilometers. The degree to which the landfill site poses a risk to the quality of groundwater depends on the linkage between the three elements (source, pathway, and receptor). A specific-site risk assessment and management based on real-time data monitoring network and system along with a consistent regulatory framework of regulations and legislation facilitate early detection of potential risks associated with the operation of sanitary landfills and unauthorized dumping and intrusion of seawater. One of the main issues and challenges to sustainably managing the groundwater resources in terms of quantity and quality is the lack of reliable and informative data that could lead to inadequate and fragile plans and policies (Ranjith, 2012; Miezah et al., 2015). 
Table 6. Calculated distances $(\mathrm{km})$ between water samples and landfills.

\begin{tabular}{|c|c|c|c|c|c|c|c|}
\hline \multirow[b]{2}{*}{ Sample } & \multicolumn{7}{|c|}{ Landfill } \\
\hline & $\begin{array}{l}\text { Almustadama } \\
22^{\circ} 39^{\prime} 19.00^{\prime \prime N} \\
39^{\circ} 12^{\prime} 46.23^{\prime \prime} \mathrm{E}\end{array}$ & $\begin{array}{l}\text { Rabigh } \\
22^{\circ} 38^{\prime} 51.62^{\prime \prime N} \\
39^{\circ} 11^{\prime} 43.75^{\prime \prime} \mathrm{E}\end{array}$ & $\begin{array}{l}\text { Afaq } \\
22^{\circ} 39^{\prime} 4.39^{\prime \prime} \mathrm{N} \\
39^{\circ} 11^{\prime} 19.37^{\prime \prime} \mathrm{E}\end{array}$ & $\begin{array}{l}\text { SEPCO } \\
22^{\circ} 39^{\prime} 40.79^{\prime \prime} \mathrm{N} \\
39^{\circ} 11^{\prime} 26.74^{\prime \prime} \mathrm{E}\end{array}$ & $\begin{array}{l}\text { Phil } \\
22^{\circ} 39^{\prime} 22.28^{\prime \prime N} \\
39^{\circ} 11^{\prime} 29.33^{\prime \prime} \mathrm{E}\end{array}$ & $\begin{array}{l}\text { GEMS } \\
22^{\circ} 39^{\prime} 33.95^{\prime \prime N} \\
39^{\circ} 11^{\prime} 6.27^{\prime \prime} \mathrm{E}\end{array}$ & $\begin{array}{l}\text { Al-Baladiya } \\
22^{\circ} 39^{\prime} 35.79^{\prime \prime} \mathrm{N} \\
39^{\circ} 10^{\prime} 4.27^{\prime \prime} \mathrm{E}\end{array}$ \\
\hline $\begin{array}{l}\text { 4BW1-Wastewater disposal site } 22^{\circ} 38^{\prime} 14.40^{\prime \prime} \mathrm{N} \\
39^{\circ} 10^{\prime} 49.9^{\prime \prime} \mathrm{E}\end{array}$ & 3.8 & 1.9 & Afaq & 2.9 & 2.4 & 2.5 & 2.8 \\
\hline $\begin{array}{l}\text { AW1-Almustadama landfill } \\
22^{\circ} 39^{\prime} 12.20^{\prime \prime} \mathrm{N} 39^{\circ} 12^{\prime} 31.50^{\prime \prime} \mathrm{E}\end{array}$ & Almustadama & 1.5 & 2.0 & 2.0 & 1.8 & 2.5 & 4.3 \\
\hline $\begin{array}{l}\text { AW2-Almustadama landfill } \\
22^{\circ} 39^{\prime} 12.00^{\prime \prime} \mathrm{N} 39^{\circ} 12^{\prime} 30.00^{\prime \prime} \mathrm{E}\end{array}$ & Almustadama & 1.5 & 2.0 & 2.0 & 1.8 & 2.5 & 4.3 \\
\hline $\begin{array}{l}\text { BW1-GEMS landfill } 22^{\circ} 39^{\prime} 43.00^{\prime \prime} \mathrm{N} \\
39^{\circ} 11^{\prime} 12.00^{\prime \prime E}\end{array}$ & 2.7 & 1.8 & 1.2 & 0.4 & 0.8 & GEMS & 2.0 \\
\hline $\begin{array}{l}\text { BW2-GEMS landfill } 22^{\circ} 39^{\prime} 43.70^{\prime \prime} \mathrm{N} \\
39^{\circ} 11^{\prime} 12.60^{\prime \prime} \mathrm{E}\end{array}$ & 2.7 & 1.8 & 1.2 & 0.4 & 0.8 & GEMS & 2.0 \\
\hline $\begin{array}{l}\text { 3BW1-Phil landfill } 22^{\circ} 39^{\prime} 22.80^{\prime \prime} \mathrm{N} \\
39^{\circ} 11^{\prime} 32.60^{\prime \prime E}\end{array}$ & 2.0 & 1.0 & 0.6 & 0.5 & Phil & 0.8 & 2.6 \\
\hline $\begin{array}{l}\text { 3BW2-SEPCO landfill } 22^{\circ} 39^{\prime} 39.40 " \mathrm{~N} \\
39^{\circ} 11^{\prime} 20.70^{\prime \prime E}\end{array}$ & 2.5 & 1.5 & 1.0 & SEPCO & 0.5 & 0.4 & 2.0 \\
\hline $\begin{array}{l}\text { 3CW1-Phil landfill } 22^{\circ} 39^{\prime} 20.10^{\prime \prime} \mathrm{N} \\
39^{\circ} 11^{\prime} 39.10^{\prime \prime} \mathrm{E}\end{array}$ & 2.0 & 1.0 & 0.6 & 0.5 & Phil & 0.8 & 2.6 \\
\hline $\begin{array}{l}\text { 3CW2-Afaq landfill } 22^{\circ} 39^{\prime} 9.00^{\prime \prime} \mathrm{N} \\
39^{\circ} 11^{\prime} 9.10^{\prime \prime} \mathrm{E}\end{array}$ & 2.7 & 1.0 & Afaq & 1.0 & 0.7 & 0.7 & 2.0 \\
\hline $\begin{array}{l}\text { 4BW2-Nabe'a Farm } 22^{\circ} 45^{\prime} 24.40^{\prime \prime N} \\
39^{\circ} 15^{\prime} 36.30^{\prime \prime} \mathrm{E}\end{array}$ & 12.3 & 13.8 & 13.9 & 12.8 & 13.3 & 13.4 & 14.4 \\
\hline $\begin{array}{l}\text { 5AW1-Rashid Farm } 22^{\circ} 42^{\prime} 5.70^{\prime \prime} \mathrm{N} \\
39^{\circ} 12^{\prime} 51.10^{\prime \prime} \mathrm{E}\end{array}$ & 5.0 & 6.0 & 6.0 & 5.0 & 5.5 & 5.5 & 6.6 \\
\hline $\begin{array}{l}\text { 6AW1-Salih Farm 2244'33.40"N } \\
39^{\circ} 13^{\prime} 48.90^{\prime \prime} \mathrm{E}\end{array}$ & 9.9 & 11.2 & 11.0 & 9.9 & 10.4 & 10.4 & 11.2 \\
\hline $\begin{array}{l}\text { 6BW1-Jama'an Farm } 22^{\circ} 45^{\prime} 11.20^{\prime \prime} \mathrm{N} \\
39^{\circ} 15^{\prime} 18.40^{\prime \prime} \mathrm{E}\end{array}$ & 11.7 & 13.3 & 13.2 & 12.2 & 12.6 & 12.7 & 13.7 \\
\hline $\begin{array}{l}\text { 6CW1-Kuleya Village } 22^{\circ} 38^{\prime} 11.20^{\prime \prime} \mathrm{N} \\
39^{\circ} 9^{\prime} 18.40^{\prime \prime E}\end{array}$ & 6.2 & 4.3 & 3.8 & 4.6 & 4.3 & 3.9 & 2.9 \\
\hline
\end{tabular}




\subsection{Linear Regression Modelling}

Results of the linear regression modeling show that the relationships between the investigated variables fall between a moderate to a very strong relationship. The correlation coefficients range between 0.524 and 0.999 . The minimum correlation coefficient was found between $\mathrm{K}$ and the $\mathrm{HCO} 3(\mathrm{r}=0.524)$ whereas the maximum was observed between $\mathrm{Cl}$ and $\mathrm{EC}(\mathrm{r}=$
0.999). Table 7 shows the correlation coefficients. The best model developed between the $\mathrm{Cl}$ and the EC associated with the highest correlation coefficient of $(r=0.999)$ is demonstrated in Figure 2. A very strong correlation coefficient was also linked to other relationships such as the model between the $\mathrm{Na}$ and the $\mathrm{Cl}$ (Figure 3) and the $\mathrm{Na}$ and the EC (Figure 4). Figure 5 shows a moderate negative relationship between $\mathrm{HCO} 3$ and $\mathrm{K}$.

Table 7. The correlation coefficient $(r) *$ of linear models of various parameters of water samples.

\begin{tabular}{|c|c|c|c|c|c|c|c|c|c|}
\hline Element & $\mathbf{N a}$ & $\mathbf{C a}$ & $\mathbf{M g}$ & $\mathbf{K}$ & $\mathbf{C l}$ & $\mathbf{S O 4}$ & $\mathbf{H C O 3}$ & TDS & EC \\
\hline $\mathbf{N a}$ & 1 & 0.922 & 0.915 & 0.916 & 0.994 & 0.917 & 0.639 & 0.988 & 0.995 \\
\hline $\mathbf{C a}$ & 0.922 & 1 & 0.979 & 0.772 & 0.956 & 0.748 & 0.660 & 0.958 & 0.955 \\
\hline $\mathbf{M g}$ & 0.916 & 0.979 & 1 & 0.804 & 0.947 & 0.786 & 0.613 & 0.935 & 0.948 \\
\hline $\mathbf{K}$ & 0.916 & 0.773 & 0.804 & 1 & 0.893 & 0.927 & 0.524 & 0.888 & 0.994 \\
\hline $\mathbf{C l}$ & 0.994 & 0.956 & 0.947 & 0.894 & 1 & 0.887 & 0.672 & 0.995 & 0.999 \\
\hline SO4 & 0.961 & 0.758 & 0.786 & 0.928 & 0.888 & 1 & 0.600 & 0.869 & 0.891 \\
\hline HCO3 & 0.639 & 0.660 & 0.613 & 0.524 & 0.672 & 0.600 & 1 & 0.658 & 0.656 \\
\hline TDS & 0.988 & 0.958 & 0.936 & 0.888 & 0.995 & 0.869 & 0.658 & 1 & 0.995 \\
\hline EC & 0.995 & 0.956 & 0.948 & 0.898 & 0.999 & 0.891 & 0.656 & 0.995 & 1 \\
\hline
\end{tabular}

\section{* Confidence level: $95 \%$}

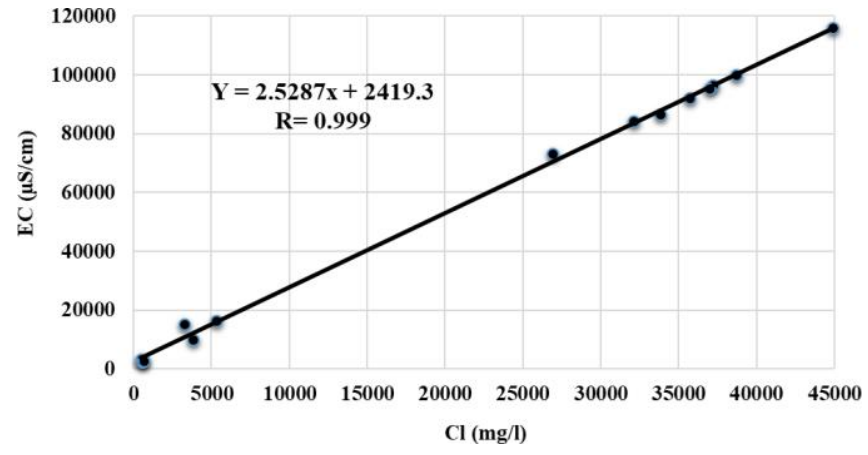

Figure 2 Linear regression model between the Chloride $(\mathrm{Cl})$ and the Electrical Conductivity (EC).

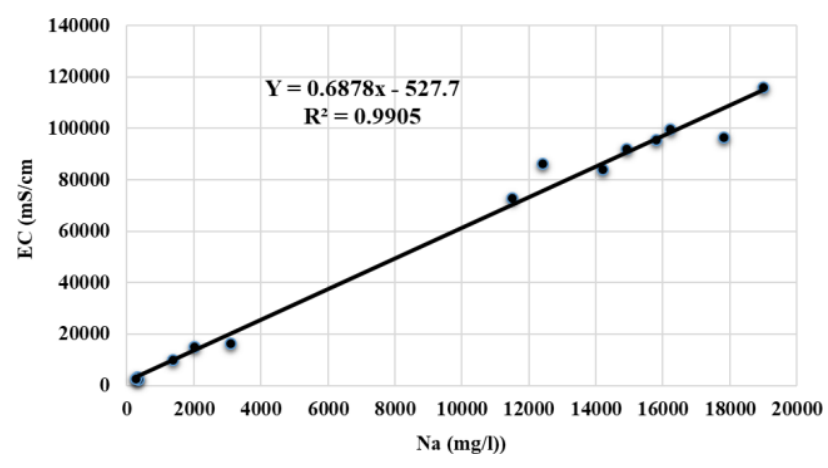

Figure 4 Linear regression model between the Sodium ( $\mathrm{Na}$ ) and the Electrical Conductivity (EC).

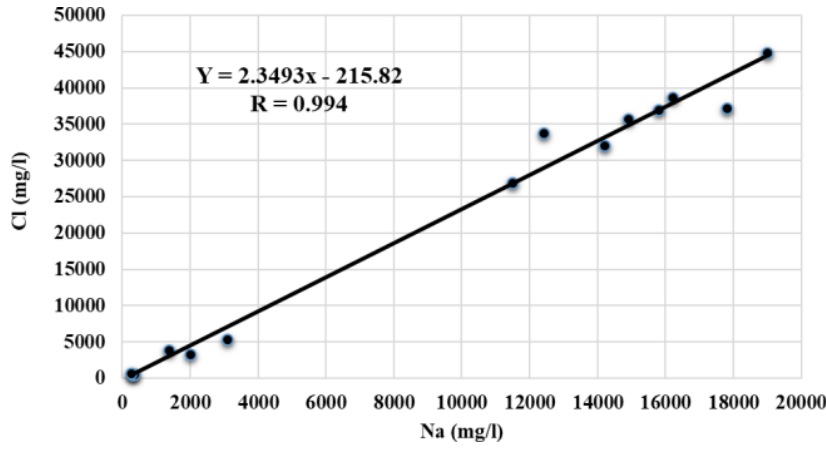

Figure 3 Linear regression model between the Sodium $(\mathrm{Na})$ and the Chloride $(\mathrm{Cl})$.

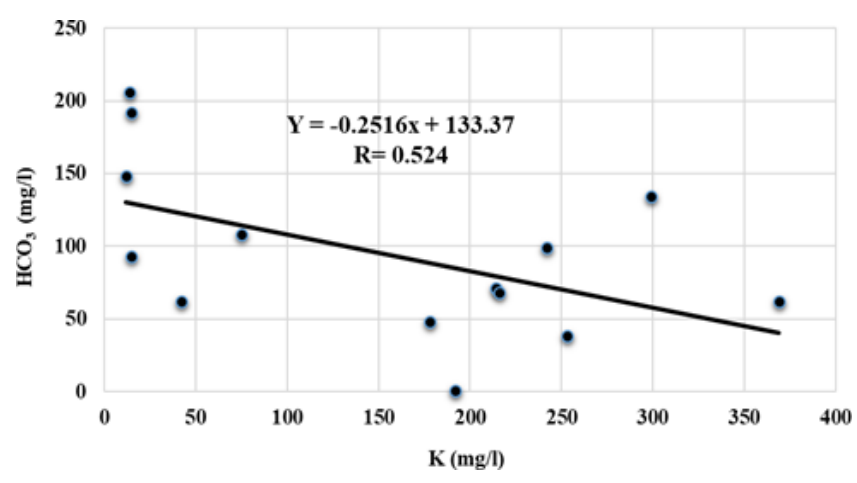

Figure 5 Linear regression model between the Bicarbonate ( $\mathrm{HCO} 3)$ and the Potassium $(\mathrm{K})$. 


\section{Conclusions and Recommendations}

\subsection{Conclusions}

This research aimed to examine the suitability of groundwater quality in Rabigh for irrigation using various water quality measures. Outcomes of this study support water managers and decision-makers in designing a robust plan and determining appropriate actions coupled with using integrated water resources management tools to sustainably use and protect groundwater from possible contamination sources, and to initiate a scheme of sustainable groundwater development and agriculture in the area.

Seven indices namely sodium percentage $(\mathrm{Na} \%)$, Sodium Adsorption Ratio (SAR), Magnesium hazard (MH), Permeability Index (PI), Total hardness (TH), Kelley's ratio, and Soluble Sodium Percentage (SSP) were used to assess the suitability of groundwater in Rabigh for irrigation purpose. Wilcox and the FAO standard limits were also considered.

The domination of ions was in the order of $\mathrm{Na}>\mathrm{Ca}>\mathrm{Mg}>\mathrm{K}$ and $\mathrm{Cl}>\mathrm{SO} 4>\mathrm{HCO} 3$ for cations and anions, respectively. Elevated concentration of $\mathrm{Na}$ and $\mathrm{Cl}$ associated with a very strong relationship between $\mathrm{Na}$ and $\mathrm{Cl}(\mathrm{r}=0.994)$, $\mathrm{Na}$ and $\mathrm{EC}(\mathrm{r}=0.995)$, and between $\mathrm{Cl}$ and $\mathrm{EC}(\mathrm{r}=0.999)$ represents effects of Seawater intrusion and indicates the vulnerability of groundwater to Red Sea invasion. According to Wilcox and the FAO classifications of salinity (EC) in irrigation water, it can be concluded that the groundwater in the investigated area of Rabigh is undesirable for irrigation purposes.

A set of linear regression models associated with moderate to very strong correlation coefficients was established between various ions. Among the best models, the strength of the correlation coefficient was in order $\mathrm{Cl}-\mathrm{EC}>\mathrm{Na}-\mathrm{EC}=\mathrm{TDS}-\mathrm{EC}=\mathrm{TDS}-\mathrm{Cl}>\mathrm{Na}-\mathrm{Cl}=\mathrm{EC}-$ $\mathrm{K}$. The corresponding correlation coefficients are $0.999,0.995,0.995,0.995,0.994$, and 0.994, respectively. A moderate negative relationship was seen between $\mathrm{HCO} 3$ and other parameters associated with a correlation coefficient that falls between 0.524 and 0.672 .

Based on the Freeze and Cherry classification of TDS, the ground water samples fall under the brackish to saline categories. However, saline water was recognized in the majority of the samples $(64 \%)$. Concerning the FAO classification, $86 \%$ of the samples were classified under severe restriction for irrigation.
Concerning the categorization of irrigation water based on sodium percentage, two-thirds of the water samples are in the doubtful to unsuitable categories. The very high electrical conductivity values obtained in the groundwater samples near the landfill sites are an indication of the combined effect of leachate and the Red Sea saltwater intrusion.

SAR serves as a universal measure to assess the suitability of irrigation water for agriculture. The severe restriction is associated with $65 \%$ of the groundwater samples according to the FAO classification of SAR. Nearly two-thirds of the groundwater samples fall under the medium to high sodium hazard categories. According to Kelley's ratio and soluble sodium percent, the majority of the groundwater samples $(86 \%)$ show that groundwater is undesirable for irrigation purposes. The analytical results of SSP conclude that the majority of groundwater samples $(86 \%)$ are undesirable for irrigated agriculture.

Analysis of total hardness reveals the $57 \%$ of the samples fall under the very hard category. However, about two-thirds of the samples are under hard to very hard categories, which would affect crop yields. The $\mathrm{Mg}$ ratios suggest that the majority of the samples (93\%) fall under a suitable category.

The areas adjacent to landfill sites experience unauthorized dumping of solid wastes and disposal of wastewaters. Results showed that samples were taken from unauthorized wastewater disposal site and some groundwater wells within the area of the landfill are contaminated by elevated concentrations of some heavy metals such as Aluminium (Al), Cobalt (Co), Copper $(\mathrm{Cu})$, Chromium (Cr), Nickel (Ni), Vanadium $(\mathrm{V})$, and Zinc $(\mathrm{Zn})$, which are above permissible limits recommended by the FAO. The sample taken from the unlicensed site of wastewaters disposal shows also high concentrations of Iron and Manganese that exceeded the corresponding permissible limits. This suggests that the indiscriminate dumping of solid waste and disposal of wastewaters have a direct impact on groundwater quality and should be discouraged. These wastes generate pollutants that pose significant risks to public health and the environment if not adequately monitored and managed. The elevated concentrations of some heavy metals in the groundwater wells that are located within and near the landfill sites imply that the proximity to an open dumpsite, wastewater disposal site, or landfill site is crucial to the groundwater contamination.

The effect of distance from a permitted landfill site, unlicensed dumpsite, unlicensed wastewater disposal 
site, and Seawater on groundwater contamination needs further investigations by drilling a set of observation wells at various distances to establish a proper correlation between distance and contamination. The overall conclusion indicates that the groundwater quality in the study area is not suitable for irrigation.

\subsection{Recommendations}

The main environmental concern in this study is the combined effect of landfills leachate and saltwater intrusion of the Red Sea on groundwater quality and its suitability for irrigation purposes. The results support recommendations that are not limited to the current situation but could be considered of value to closed or unlicensed dump sites and/or unlicensed wastewaters disposal as well as new landfills that require continuous monitoring as part of environmental risks assessments. The key recommendations are:

1. Design and establish a site-specific real-time data monitoring network based on the source-pathway-receptor linkage taking into account that groundwater plays the role of both pathway and receptor. The monitoring network of water quality and water level sensors and associated management programme should comply with regulatory standards of groundwater quality and landfill permission plan and implementation.

2. The vulnerability of groundwater should be evaluated against the potential hazards posed by a source (i.e. landfill leachate and salt water intrusion of the Red Sea) and whether or not there are any migration pathways which can allow contaminants to migrate from the source to the receptor.

3. Monitoring should be considered as a central part of a long-term risk assessment programme.

4. Observation wells should be drilled at various distances to properly monitor contaminant levels. The location of the observation wells should provide a full image of the spatial and temporal contamination with distance.

5. Further research work needs to be carried out considering a larger sample size of groundwater associated with the analysis of soil and leachate samples.

\section{Acknowledgment}

The authors would like to thank The General Authority for Meteorology and Environmental Protection (GAMEP) Kingdom of Saudi Arabia for providing data and information to successfully carry out this research.

\section{References}

Al-Ahmadi, M. E., 2012. Interpretation Of Groundwater Quality Using Factor Analysis, Wadi Rabigh Area, Western Saudi Arabia. Environmenta Hydrology, Volume 20.

Al-Faraj, F. A. \& Al-Dabbagh, B. N., 2015. Assessment of collective impact of upstream watershed development and basin-wide successive droughts on downstream flow regime: The Lesser Zab transboundary basin. Journal of Hydrology, Volume 530, pp. 419-430.

Al-Faraj, F. A. \& Scholz, M., 2014. Assessment of temporal hydrologic anomalies coupled with drought impact for a transboundary river flow regime: The Diyala watershed case study. Journal of Hydrology, Volume 517, p. 64-73.

Alfarrah, N. \& Walraevens, K., 2018. Groundwater Overexploitation and Seawater Intrusion in Coastal Areas of Arid and Semi-Arid Regions. Water 2018, 10, 143, 10(143), pp. 1-24.

Al-Hasawi Z.M and Hussein K.H, 2012. Groundwater investigation in Rabigh Governorate, West of Saudi Arabia. Advanced Research Journals, 1(4) (July, 2012 ), pp. 072-079.

Bhat, M. A., Wani, S.A., Singh, V.K., Shoo, J., Tomar, D., and Sanswai, R., 2018. An Overview of the Assessment of Groundwater Quality for Irrigation. Journal of Agricultural Science and Food Research, 9(1), pp. 1-9.

Bougioukou, G., Papadopoulou, M. P. \& Karatzas, G. P., 2005. Landfill Leachate Impacts on Groundwater Quality: The case study of municipal Landfill of Patras. Rhodes island, Greece, the 9th International Conference on Environmental Science and Technology.

Department for Environment, Food \& Rural Affairs and Environment Agency, 2016. Landfill developments: groundwater risk assessment for leachate. Available at: https://www.gov.uk/guidance/landfilldevelopments-groundwater-risk-assessment-forleachate [Accessed 19 March 2019]. 
El-Hames, A, Al-Ahmadi, M, Al-Amri, N, 2010. A GIS approach for the assessment of groundwater quality in Wadi Rabigh aquifer, Saudi Arabia. Environmental Earth Sciences, 63(Springer-Verlag 2010), pp. 1321-1333.

Environment Agency, 2016. Gov.UK. Available at: https://www.gov.uk/government/organisations/envir onment-agency [Accessed 1 March 2019].

FAO, 2009. Groundwater Management in Saudi Arabia, Rome: Food and Agriculture Organization of the United Nations.

FAO, n.d. Water quality for agriculture. Available at: http://www.fao.org/3/T0234e/T0234E06.htm

[Accessed 1 March 2019].

Femi, F., Oluwole, O., 2013. Management of Municipal Solid Waste. Available at: http://www.acad-

emia.edu/4254191/Management_of_Municipal_Soli d_Wast [Accessed 6 January 2019].

Freeze, R. \& A.Cherry, J., 1979. Groundwater. 604p ed. Englewood Cliffes,New Jersey: PrenticeHall, Inc.

Gameh, M., Ebtehag, A., El-Habaak, G., AbdelMoneim, M., 2014. Groundwater Potentiality and Suitability for Drinking and Irrigation in the New Valley, Western Desert, Egypt. Assiut Assiut Journal of Agricultural Sciences., 45(2), pp. 113-124.

General Authority of Meteorology and Environmental Protection, 2018. Technical Environmemtal Report of Rabigh Governorate, Rabigh, Saudi Arabia: GAMEP Unpublished Technical Report.

Ibraheem, A. M. \& Khan, S. M. M. N., 2017. Assessment of Heavy Metal Concentration of Groundwater in Veppanthattai Block, Perambalur District, Tamil Nadu. World News of Natural Sciences, Volume 12, pp. 21-26.

A. Jeyaseelan, A, Narmatha, T, Mohan1, S, P, Mahalingam, S, Natchimuthu, S, 2013. Assessment of groundwater quality and its suitability for agricultural use in Nishabanathi and Kalingalar subbasins of Vaippar river basin, TN, India. J. Acad. Indus. Res, 1(11), pp. 720-725.

Joshi, D. M., Kumar, A. \& Agrawal, N., 2009. Assessment of the Irrigation Water Quality of River Ganga in Haridwar District. Rasayan Journal of Chemistry, 2(2), pp. 285-292.
Khashogji, M. S. \& Maghraby, M. M. S. E., 2012. Evaluation of groundwater resources for drinking and agricultural purposes, Abar Al Mashi area, south Al Madinah Al Munawarah City, Saudi Arabia. Arabian Journal of Geosciences , 6(10), p. 3929-3942.

Miezah, K, Obiri-Danso, K, Zsófia K, Fei-Baffoe, B, Mensah, Moses Y, 2015. Municipal solid waste characterization and quantification as a measure towards effective waste management in Ghana. Waste Management, Volume 46, pp. 15-27.

Mukherjee, S., Kumar, B.A. \& Körtvélyessy, L., 2005. Assessment Of Groundwater Quality In The South 24-Parganas, West Bengal Coast, India. Environmental Hydrology, 13(15).

Narayanamurthi, V., 2018. Assessment of Groundwater Quality Using ArcGIS for Mangadu. International Journal for Research in Applied Science \& Engineering Technology (IJRASET), 6(1), pp. 418-422.

Oyiboka, I. J., 2014. Effects Of Landfill Sites On Groundwater Quality In Igando, Alimosho Local government Area, Lagos State, Master: University of South Africa.

Prasanth, S. V. S., Magesh, N. S., Jitheshlal, K. V., Chandrasekar, N., Gangadhar, K., 2012. Evaluation of groundwater quality and its suitability for drinking and agricultural use in the coastal stretch of Alappuzha District, Kerala, India. Applied Water Science, Volume 2, p. 165-175. Ranjith, 2012. Sustainable Solid Waste Management in India.

Shah, S. M. \& Mistry, N. J., 2013. Groundwater Quality Assessment for Irrigation Use in Vadodara District, Gujarat, India. International Journal of Agricultural and Biosystems Engineering, pp. 719724.

Shammi, M, Karmakar, B, Rahman, M.M, Islam, M.S, R, Rahman, Uddin, M, 2016. Assessment of Salinity Hazard of Irrigation Water Quality in Monsoon Season of Batiaghata Upazila, Khulna District, Bangladesh and Adaptation Strategies. Pollution, 2(2), pp. 183-197.

Singh, S., Raju, N. \& Ramakrishna, C., 2015. Evaluation of Groundwater Quality and Its Suitability for Domestic and irrigation Use in parts of the Chandauli-Varanasi Region, Uttar Pradesh, India. Journal of Water Resource, Volume 7, pp. 572-587. 
Talib E. Butt, K. O. K. O. \& Lockley, E., 2008. Risk assessment of landfill disposal sites - State of the art. Waste Management, 28(6), pp. 952-64.

Venkateswaran, S. \& Vediappan, S., 2013. Assessment of Groundwater Quality for Irrigation
Use and Evaluate the Feasibility Zones through Geospatial Technology in Lower Bhavani Sub Basin, Cauvery River, Tamil Nadu, India. International Journal of Innovative Technology and Exploring Engineering, 3(2), pp. 180-187. 